\title{
HABITAT SELECTION OF SMALL MAMMALS IN A MIXED FOREST IN TURKEY
}

\author{
BULUT, Ş. $.^{*}-$ KARATAŞ, A. ${ }^{2}-$ AYAŞ, Z. ${ }^{3}$ \\ ${ }^{I}$ Hitit University, Faculty of Art and Science, Department of Molecular Biology and Genetics, \\ Çorum, Turkey \\ ${ }^{2}$ Niğde Ömer Halisdemir University, Department of Biology, Niğde, Turkey \\ ${ }^{3}$ Hacettepe University, Faculty of Science, Department of Biology, Ankara, Turkey \\ *Corresponding author \\ e-mail: safakbulut@hitit.edu.tr; phone: +90-364-227-7000 \\ (Received 25 $5^{\text {th }}$ May 2020; accepted $19^{\text {th }}$ Nov 2020)
}

\begin{abstract}
Small mammals is a non-taxonomic subgroup named on the basis of body size of individuals. This study was created from data obtained through the mark-recapture method of small terrestrial mammals in Populus tremula, thermophilic deciduous, steppes, conifer plantations and Abies sp. forest habitats in Turkey. Field studies were performed for a total of 14 months in 2014 and 2015. 758 individuals from seven species were captured in a total of 5250 days in trapping grid studies conducted in a total of 5 different types of habitat by a grid of $5 \times 5$ traps system. The average capture success in all was calculated as $14.44 \%$. The species affected by temperature data were $M$. glareolus and $D$. nitedula. It was found that $M$. subterraneus showing increasing populations was negatively correlated with temperature. When considering the sex ratios, M. glareolus was under intense male pressure in steppe habitat. Indicator species were determined numerically and M. glareolus, M. subterraneus and D. nitedula were found to be decisive species for different habitats. The habitats showing most similarity to each other in terms of habitat preferences of small mammals the pine plantation and Abies forest, the most different habitat was steppe.
\end{abstract}

Keywords: habitat preference, mark-recapture, populasyon dynamics, rodents

\section{Introduction}

Small mammals constitute a taxonomic group that can be used as an ideal model for studies in different fields (Barret, 1999). Distribution patterns of small mammals have important impacts on the biodiversity and the ecosystem (Aubry et al., 2003). Small mammal species can be classified into three trophic groups: those feeding on insects and other invertebrates (e.g. Crocidura spp.), those feeding on plant material or those that are omnivorous or graminivorous (e.g. Apodemus spp.), and those feeding on seeds (e.g. Sciurus spp.) (Kirkland Jr. et al., 1985). Consequently, the feeding behaviour of small mammals on seeds, fungi, plants, invertebrates, and bird eggs has strong effects on forest regeneration (Sullivan et al., 1993), biodiversity and the food cycle (McShea and Rappole, 2000). The effect of small mammals on forest regeneration is crucial for the entire ecosystem. Seeds dispersed by small mammals may promote this regeneration. Moreover, the mycorrhizal fungi, also dispersed by small mammals, are thought to be critical for tree growth (Luoma et al., 2003).

Species in the Rodentia order, which is represented by the highest number of species among all mammals, are one of the key components of ecosystems. This is especially true for forest ecosystems. The interactions of rodent species with other organisms and the physical environment are quite complex. These species feed on seeds and 
vegetation, which may affect the regeneration patterns of forests (Sullivan et al., 1979; Christy and Mack, 1984). Seeds, mycorrhizal fungi and nitrogen-binding bacteria spread by these species may also affect plant diversity (Verts and Carraway, 1998; Luoma et al., 2003). Furthermore, rodent species are an essential part of the diet of many carnivorous species, and thus changes in their population size may have an impact on the dispersal and habitat use of carnivorous mammals, raptors and some reptiles (Carey et al., 1992). We may say that the demography and behaviour of these species are directly related to the distribution and density of their predators. For example, a decrease in rodent populations may cause owl species to end up with a limited reproduction rate or a lower number of eggs (Korpimaki et al., 1987; Hammer et al., 2001).

In recent years, small-scale ecological studies (i.e. fauna surveys in specific regions) were conducted on the small mammals in Turkey (Özkan, 1987; Karataş, 1996; Diker, 2007; Irmak, 2012; Tüzün, 2012). In addition to faunal inventory studies, reproductive and dietary behaviours were also studied in laboratory environments (Çolak et al., 1994; Yiğit et al., 1995, 1997; Buruldağ, 1999; Özkurt et al., 2001, 2005; Özkan et al., 2003).

Gür and Kart (2005) were the first to use the marking method in Turkey, for their study on the natural environment of Anatolian ground squirrels, in which they assessed the body mass, reproduction and annual hibernation activity of this species. Gür and Barlas (2006) surveyed the sex ratios of 235 Anatolian ground squirrel specimens. Yavuz (2007) calculated the estimated population size in closed populations based on 122 European water vole specimens she caught, by using mark-recapture technique. Şenol (2012) used the marking method in his study to determine the population size of rodents in a mixed deciduous forest habitat near Zonguldak. In this study, 130 live catch traps were placed in an area of one hectare at ten meter intervals according to the grid method. Parameters such as the estimated population size per hectare, sex ratios and home range were evaluated, and it became the first study to address these issues in Turkey.

Forest management is one of the most important factors causing a disturbance on the life and biodiversity of communities in the forests and in parts of them. Although biodiversity needs to be preserved and that the forest ecosystems require long-term sustainability, clear cutting has remained the major forest management technique in many places. While the forest management may have positive effects on some species or cause some species to remain completely unaffected, it does have negative effects on some species (Duguay et al., 2000; Payer and Harrison, 2000; De Bellefeuille et al., 2001). Small mammals are the potential indicators of forest management that looks out for the protection of forests. These species play a significant role in the forests; they are biologically important as being prey items for carnivorous animals, and they display typical responses when natural damage occurs due to intervention. In different types of forest, certain small mammals are known as indicator species. Small mammals have intensely changing population dynamics even without the existence of any disruption caused by forestry activities, so longer periods are needed to determine their response to the effects of such disruptions and alteration trends (Pearce and Venier, 2005). Small mammals are very suitable as habitat alteration indicators in temperate forests (full cutting of certain areas, emerging fragmentation, intentional reforestation, or spontaneous regrowth) (Carey and Harrington, 2001). Small mammal populations have a short transformation period, and their migration patterns can be tracked, and this is 
why they are suitable for studying edge effects in ecotones between different habitat sections (Hansson, 1998; Manson et al., 1999; Nickel et al., 2003).

Small mammal populations either show a positive response or no response to the partial cutting practices in the forests (Medin and Booth, 1989; Steventon et al., 1998). Research results indicate a positive correlation between the abundance of small mammal populations and the leaf cover on the forest floor. For this reason, interventions reducing the amount of vegetation on the forest floor (i.e. herbicide application, machine correction of the land, tree plantations) also reduce the number of small mammals that feed on leaves until the subforest vegetation regrows (Lautenschlager, 1993). Small mammals also rely on the physical components of the forest, including tree stumps, overturned tree trunks, canopy openings, grass-layer vegetation, decayed trees, leaf remains and humus layer. Forest management may alter these factors significantly (Bowman et al., 2000; Carey and Harrington, 2001).

This study was compiled from the data obtained according to the "Capture-MarkRecapture" model of terrestrial small mammals living on the floor of Populus tremula Forest, Thermophilic Deciduous Forest, Steppe (Mountain Steppe), Conifer Plantation, and Abies (Fir) Forest habitats in Soğuksu National Park in Central Anatolia Region. The subject of this study is to determine: recording qualitative and quantitative data regarding small mammals by sampling forest sections with different vegetation; evaluating qualitative data on small mammal species living on the forest floor; based on their relative ratios and changes in area usage in each sampling area; comparing the community components, structure, and species richness of small mammals according to different habitat types; assisting forest management practices (cutting, seeding, etc.) in their decisions on the type of trees to be planted, and their locations.

\section{Materials and Methods}

\section{Study Area}

Our studies were carried out in Soğuksu National Park, an important natural reserve in Kizilcahamam district, in the northernmost part of Ankara in Turkey. The National Park is located between $40^{\circ} 31^{\prime} 26^{\prime \prime}-40^{\circ} 34^{\prime} 13$ " $\mathrm{S}$ latitudes and $32^{\circ} 35^{\prime} 10^{\prime \prime}-32^{\circ} 39^{\prime} 31^{\prime \prime} \mathrm{E}$ longitudes in the in the Upper Sakarya Section of Central Anatolia Region (Figure 1). The study area constitutes the Central Anatolia - Western Black Sea transition zone, and thus has a pivotal status in terms of biodiversity. As the study area is located between the geographic regions of Western Black Sea and Central Anatolia, its climate is influenced by both regions. Summers are dry and cool; winters are snowy and rainy. The area hosts Western Black Sea fir forests, Middle Black Sea pine forests, West Anatolian black pine forests, and Central Anatolian mountain steppe vegetation. The dominant forest vegetation in the area mainly consists of Quercus pubescens, Pinus nigra ssp. pallasiana, Pinus sylvestris, and Abies nordmanniana ssp. bornmuelleriana populations.

\section{Methodological Frame}

In this study, we used the multi-faceted feature of Mark-Recapture data to investigate small mammal species and to look into the differences at the community level in five different habitat types [Populus tremula Forest (G1.9), Thermophilic Deciduous Forest (G1.7), Steppe (E1.2), Conifer Plantation (G3.F), and Abies (Fir) Forest (G3. 1)] 
(Figure 1). Capturing stories collected from the sampling studies carried out with grid trapping systems were used for comparing the population densities of four small mammal species within and between mixed oak, young conifer plantation site, in-forest clearing, mixed coniferous and deciduous forest, and the coniferous forest habitats. The detection/nondetection data distributed to all habitat types was combined with covariables at the trap level and used in logistic regression in order to reveal the preferences of living things at the microhabitat level. Species richness observed at the community level was compared between and within these five habitats. In addition, the abundance of caught species in each grid system enabled us to compare the structure and composition of small mammal community in all five explored habitats.

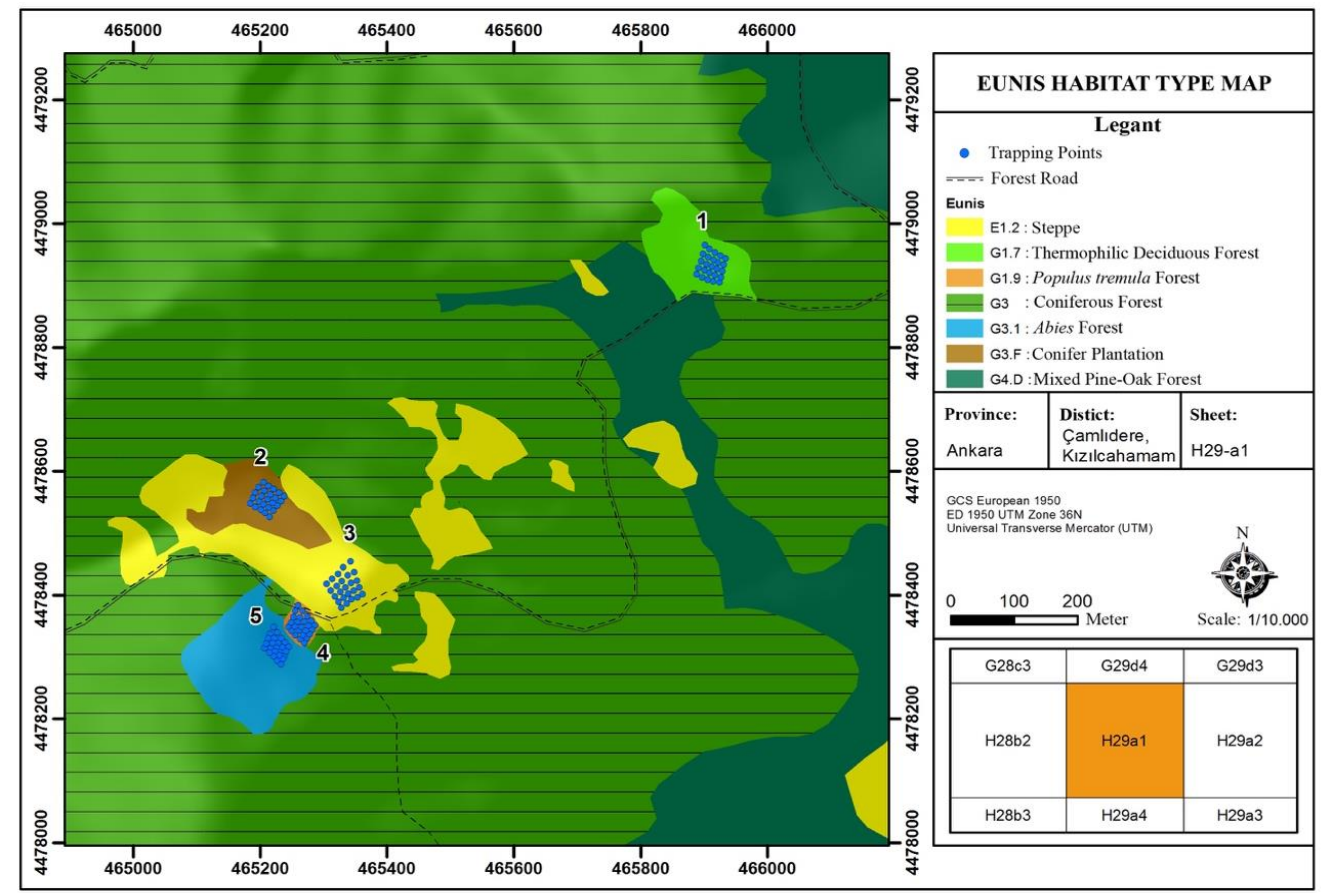

Figure 1. Study Area and EUNIS Habitat Classes Map

\section{Data Collection}

In this study, we used a square grid containing 25 trapping stations of $5 \times 5$, depending on the frequency of ground cover and undercover vegetation of the habitat (Flowerdew et al., 2004). The distance between traps was determined as $10 \mathrm{~m}$. Sherman-type live catch traps are $23 \times 9 \times 7 \mathrm{~cm}$ in size, and are among the most frequently used trap types in small mammal studies. We marked each determined trap location with numbered piles to avoid any possible confusion about trap locations. We used peanut butter and bread as bait, and marked all captured specimens with ear tags (National Band Tag Company, 1005-1). Sampling was carried out for three-day periods every month between May and November in 2014 and 2015. The number of trap days, which is calculated by multiplying the number of traps with the number of sampling days in each repetition was 525 for a one-year sampling period, 1,250 during the entire fieldwork, and 5,250 in total for selected five different habitats. The sampling was carried out with the permission of Hacettepe University, Experiment Animals Ethics Committee dated 03.26.2014, no. 52338575-41. 


\section{Statistical Analyses}

Since there were five habitats for each species (since $n<30$ ), we used the KruskalWallis test to find out the differences between the capturing frequency of the species in all areas and the capturing rates according to months, and the Mann-Whitney U test to compare the differences in pairs $(\mathrm{p}<0.05$ for all dual comparisons). The capturing numbers for species in individual habitat types were compared with the $\chi^{2}$ test. All relationships between the vegetation structure, relative population density depending on temperature, and other quantitative small mammal data were tested by using regression analysis (Zar, 1996). Multiple regression analysis was used to test the relationship of quantitative small mammal data (mean number of captures, relative abundance value of common species) in terms of total and habitat-based effects of the selected five different habitat types.

The characteristic species of different habitats were determined by IndVal (Indicator Value) method, a relatively new statistical procedure (Dufrene and Legendre, 1997). We used IndVal 2.0 to determine the indicator values. IndVal also generates significance values for the calculated indicator values, based on random selection calculations. For the IndVal method, it is necessary to assign codes to the habitats based on the five forest habitats studied. The Bray-Curtis index was applied to calculate the similarities between habitats based on quantitative data of different species. Similarity structure was obtained using a hierarchical cluster analysis, and UPGMA was calculated to combine the data.

Diversity indices (Shannon-Weiner, Margalef species richness and Simpson indices) were used to obtain data about species richness and the distribution of individuals among species in habitats (grids). These indices were calculated using the Past 3.13 program.

\section{Results}

\section{Habitat Types}

Thermophilic Deciduous Forest (G1.7): These forests thrive on the andesite bedrock between 1,470 and 1,590 metres in Soğuksu National Park. They have 80-90\% coverage, and a height of 6-7 metres. The dominant species are Quercus petraea ssp. iberica, Sorbus torminalis, Crataegus tanacetifolia, and Carpinus betulus. Pinus nigra was sparsely found in these forests.

Conifer Plantation (G3.F): Some parts of Soğuksu National Park are afforested, mainly with Scots pine (Pinus sylvestris). Species in the plantation are 15-20 years old, and are quite dense. Therefore, the floristic composition in this area developed rather poorly.

Steppe (E1.2): This is the most common habitat in the Central Anatolia Region. Usually found in the hills called steppes, it may also grow in forest openings. This habitat that develops in the forest openings in Soğuksu National Park is used as a pasture. The dominant species are herbaceous species such as Astragalus microcephalus, Stipa holosericea, Dactylis glomerata, and Vicia caracca. This habitat, composed of single-layer herbaceous species, has a cover of $100 \%$, and a height between 10 and $150 \mathrm{~cm}$.

Populus tremula Forest (G1.9): Populus tremula forests are distributed on andesite rocks at altitudes of 1,400-2,000 $\mathrm{m}$ in Soğuksu National Park, and are generally found 
in the more humid areas on the northern slopes. These forests can be pure, or mixed with forests of Pinus sylvestris and Abies nordmanniana subsp. bornmuelleriana. The soil is rich in organic matter.

Abies Forest (G3.1): This habitat represents the pure Abies nordmanniana ssp. bornmuelleriana forests in Soğuksu National Park. Its floristic composition was observed to be weak. It may rarely include deciduous forest members such as Pinus sylvestris and Sorbus torminalis. These forests may have a cover of $100 \%$, and a height of 10-15 metres. The soil is rich in organic matter.

\section{Trapping Ratios and Habitat Choices}

In trapping studies carried out in 5 different habitat types according to the $5 \times 5$ square grid system, we caught 758 individuals from 7 different species in a total of 5,250 trap days. The mean capturing success in all habitat types was calculated as $14.44 \%$. During the entire study, the most commonly captured species was Mus macedonicus (115 individuals) and the rarest was Dryomys nitedula (9). The habitat type represented by the highest number of individuals was Populus tremula forest $(P t \mathrm{~F})$, followed by Thermophilic Deciduous Forest (TDF), steppe (STP), conifer plantation $(\mathrm{CP})$ and Abies (Fir) forest $(A \mathrm{~F})$ in order. Capturing rates according to habitats are given in Table 1.

Table 1. The number of individuals captured in habitats

\begin{tabular}{c|c|c|c|c|c|c|c}
\hline Grid & Apodemus spp. & M. macedonicus & M. glareolus & M. subterraneus & C. suaveolens & D. nitedula & Total \\
\hline PtF & 139 & 24 & 57 & 19 & 7 & 2 & $\mathbf{2 4 8}$ \\
TDF & 154 & 6 & 13 & 9 & 6 & 7 & $\mathbf{1 9 5}$ \\
STP & 29 & 12 & 16 & 46 & 15 & 0 & $\mathbf{1 1 8}$ \\
CP & 53 & 34 & 9 & 11 & 4 & 0 & $\mathbf{1 1 1}$ \\
AF & 41 & 39 & 2 & 3 & 1 & 0 & $\mathbf{8 6}$ \\
\hline Total & $\mathbf{4 1 6}$ & $\mathbf{1 1 5}$ & $\mathbf{9 7}$ & $\mathbf{8 8}$ & $\mathbf{3 3}$ & $\mathbf{9}$ & $\mathbf{7 5 8}$ \\
\hline
\end{tabular}

PtF: Populus tremula Forest, TDF: Thermophilic Deciduous Forest, STP: Steppe, CP: Conifer Plantation, AF: Abies sp. Forest

Morphological distinction of Apodemus flavicollis and A. witherbyi can be quite difficult. Therefore, these two species were grouped as Apodemus spp. to avoid misidentification. According to this, the most preferred habitat types of species belonging to the genus Apodemus, which had the highest number of individuals in forest habitats, were TDF and $P t \mathrm{~F}$. Other preferred habitat types were $A \mathrm{~F}$ and $\mathrm{CP}$ for $M u s$ macedonicus, PtF for Myodes glareolus, and mountain steppe for Microtus subterraneus. A total of 33 Crocidura suaveolens specimens were captured, and this species generally does not use undercover fir forest floor. Dryomys nitedula individuals were seen as thermophilic deciduous forest animals. They were also observed in $P t \mathrm{~F}$, but not in other habitats (Figure 2).

In order to test whether there was a statistical difference between the capturing frequencies of species, capturing frequencies in the entire study area were analysed with the Kruskal-Wallis test since there were 5 different habitats for each species $(n<30)$. The results showed a statistically significant difference between the capturing frequencies of species $(\mathrm{KW}-H(5 ; 30)=18.2389 ; \mathrm{p}=0.0027)$ (Figure 3). 


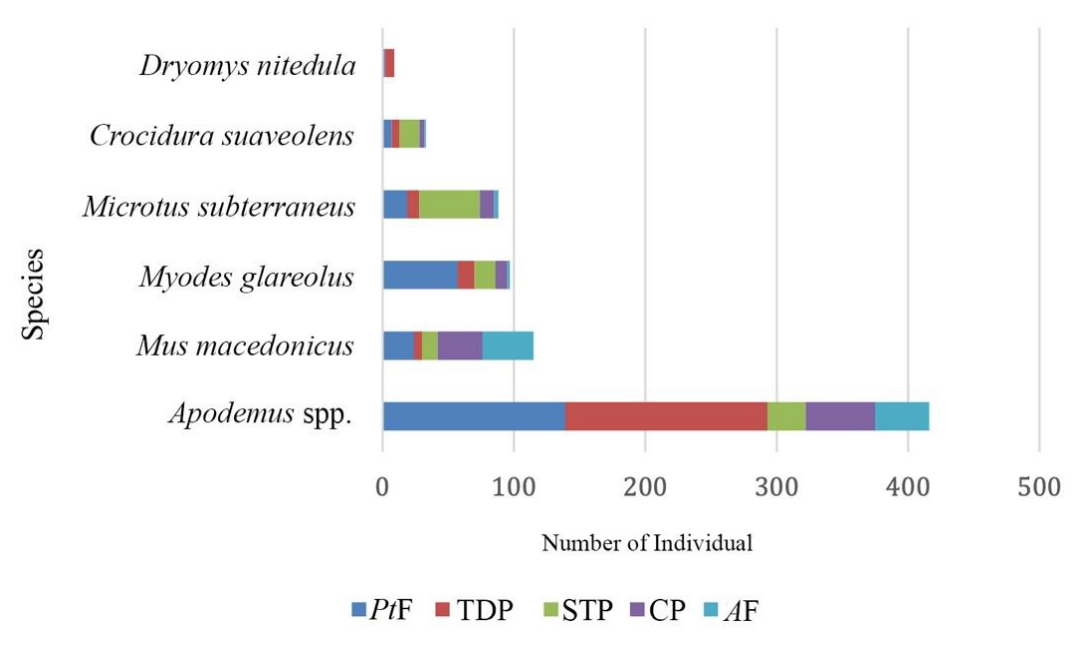

Figure 2. Habitat preferences of species (PtF: Populus tremula Forest, TDF: Thermophilic Deciduous Forest, STP: Steppe, CP: Conifer Plantation, AF: Abies sp. Forest)

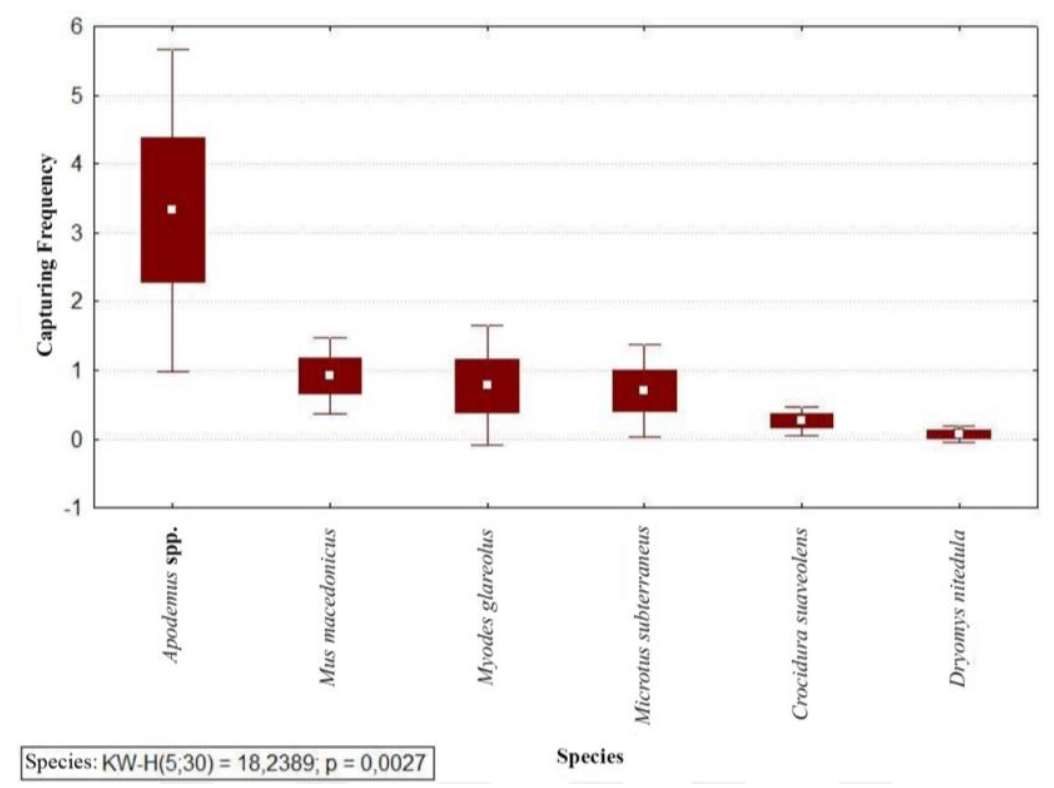

Figure 3. Distribution of capturing frequency according to species

The differences between the double capture rates of the species were compared with the Mann-Whitney $U$ test ( $\mathrm{p}<0.05$ for all dual comparisons). Upon examining dual comparisons, we determined that the capturing rate of Apodemus spp. in the study area was different from those of $C$. suaveolens and D. nitedula, meaning Apodemus had a higher density. The capturing numbers of species in individual habitat types were compared with the $\chi^{2}$ test. According to this, the difference was significant for Apodemus spp. $(\chi 2=165.3462 ; p=0.000000)$, M. macedonicus $(\chi 2=34.26087$; $\mathrm{p}=0.000001), M$. glareolus $(\chi 2=96.76289 ; \mathrm{p}=0.000000)$, M. subterraneus $(\chi 2=64.72727 ; \mathrm{p}=0.000000)$, and $C$. suaveolens $(\chi 2=16.54545 ; \mathrm{p}=0.002369) ;$ but not for $D$. nitedula $(\chi 2=0.4 ; \mathrm{p}=0.982477)$. When sex ratios were compared between habitats, the differences for all species in all five habitats are not significant $(\mathrm{p}<0.05$ for all double comparisons). 


\section{Indicator Values of Species}

In order to evaluate the captured small mammals at the community level, their indicator values in different habitats were found. Results obtained by using a method that also includes multivariate statistical methods, can be seen related to the relationship between small mammals and the habitats or microhabitats they occupy. Indicator analysis was performed for spring, summer, autumn, and for combined seasonal data. We first created a table for indicator species with three separate periods, and determined the data for certain species and five sampling grids for each season. A maximum 0.46 IndVal was found for Apodemus spp., but this data was not significant $(P=1.178)$. Mus macedonicus and Crocidura suaveolens also gave low IndVal values, and thus were not evaluated as indicator species for a particular habitat. Myodes glareolus generally preferring a specific habitat and also being seen in other habitats (although rare), Microtus subterraneus being the dominant species of the steppe, and Dryomys nitedula preferring thermophilic deciduous forest increased their indicator species values (Table 2, Figure 4).

Table 2. Maximum IndVal of species with hierarchical classification

\begin{tabular}{c|c|c|c|c|c|c}
\hline Species & IndVal (\%) & PtF & TDF & STP & CP & AF \\
\hline Apodemus spp. & 46.17 & $139 / 25$ & $154 / 25$ & $29 / 17$ & $53 / 23$ & $41 / 19$ \\
Mus macedonicus & 29.60 & $24 / 13$ & $6 / 4$ & $12 / 7$ & $34 / 16$ & $39 / 21$ \\
Myodes glareolus & $42.15 *$ & $57 / 22$ & $13 / 6$ & $16 / 5$ & $9 / 4$ & $2 / 2$ \\
Microtus subterraneus & $63.84 * *$ & $19 / 11$ & $9 / 4$ & $46 / 22$ & $11 / 4$ & $3 / 2$ \\
Crocidura suaveolens & 17.11 & $7 / 4$ & $6 / 3$ & $15 / 8$ & $4 / 3$ & $1 / 1$ \\
Dryomys nitedula & $69.21 * *$ & $2 / 1$ & $7 / 4$ & $0 / 0$ & $0 / 0$ & $0 / 0$ \\
\hline Total & & $248 / 76$ & $195 / 46$ & $118 / 59$ & $111 / 50$ & $86 / 45$ \\
\hline
\end{tabular}

The first number in each habitat is the number of individuals captured in that habitat, and the second value is the number of trap locations where species are captured in that habitat. **: $P<0.01$; $*: P<0.05$

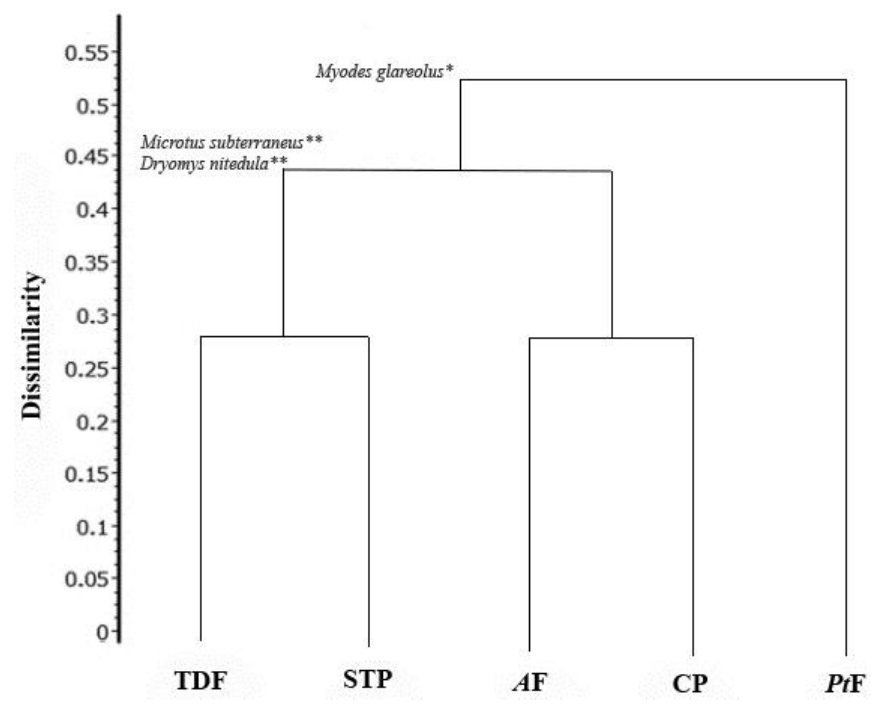

Figure 4. Dendrogram of the maximum indicator values on a certain hierarchical level, and the habitats analysed according to the significant IndVal values closest to the maximum value

(Bray-Curtis index-UPGMA) 


\section{Habitat Diversity and Similarities}

According to the results for five different habitat types in Soğuksu National Park, some habitats have equal numbers of species, but have different characteristics as these species may be found in different proportions. To understand this difference numerically, we calculated the habitat similarities according to the Bray-Curtis similarity index. Habitats with the highest similarities were found between the coniferous plantation and Abies forest (82.2\%), and between the Populus tremula forest and thermophilic deciduous forest (79\%). Similarities of other habitats were low. We drew a dendrogram of habitat similarities according to the Bray-Curtis similarity index. Populus tremula forest, thermophilic deciduous forest, and the steppe habitat appear to be on a different branch than the coniferous plantation and Abies forest. The steppe habitat is also separated from the Populus tremula forest and thermophilic deciduous forest (Figure 5).

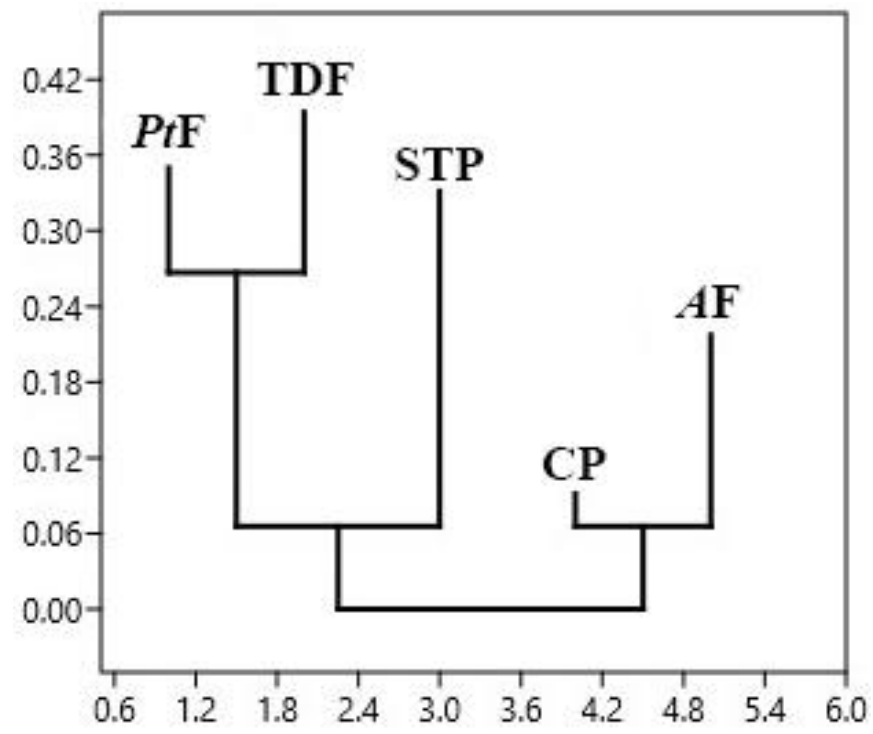

Figure 5. Dendrogram for habitat similarities according to the Bray-Curtis similarity index (Bray-Curtis index UPGMA)

Diversity indices of all five habitat types were calculated based on the number of small mammals captured in each of them during field studies (Table 3). The Simpson diversity index indicates the diversity of a habitat, with a value between 0 and 1 . The diversity decreases as the $D$ value approaches 1 . According to this, the thermophilic deciduous forest was found to have the highest diversity $(D=0.3665)$. The ShannonWeiner index is used to numerically demonstrate the species diversity in an area, and the $H$ value ranges from 0 to 5. Accordingly, the steppe habitat was found to be the richest in species diversity $(H=1.478)$. Margalef index transforms the species richness of a habitat into a numerical value, and this value has no limit. The habitat with the highest value in the Margalef index has the highest species richness. Accordingly, the thermophilic deciduous forest was found to be have the highest species richness $(M=0.9482)$. However, values from all habitats were close to each other. 
Table 3. Diversity indices of habitats

\begin{tabular}{c|c|c|c|c|c}
\hline & PtF & TDF & STP & CP & AF \\
\hline Number of Species & 6 & 6 & 5 & 5 & 5 \\
Number of Individuals & 248 & 195 & 118 & 111 & 86 \\
\hline Simpson_1-D & 0.6169 & 0.3665 & 0.7427 & 0.6605 & 0.5652 \\
Shannon_H & 1.225 & 0.8426 & 1.478 & 1.268 & 0.9681 \\
Margalef & 0.9069 & 0.9482 & 0.8385 & 0.8493 & 0.898 \\
\hline
\end{tabular}

\section{Discussion}

Trapping studies in 5 different habitat types conducted with the $5 \times 5$ square grid system yielded 758 individuals from 7 different species in a total of 5250 trap days. The mean capturing success in all habitat types was calculated as $14.44 \%$. Şenol (2012) captured 610 individuals in a mixed deciduous forest habitat on the Black Sea coast in 4680 trap days, with a trap success of $13.03 \%$. The study continued during the winter months, and the capturing success was not affected by the winter as the study area was a coastal region. For example, Wells et al. (2007) captured 17 species in the rainforest during 17800 trap nights, achieving a trap success of $28.3 \%$, while Nakagawa et al. (2006) achieved similar results by capturing 22 species in 6821 trap nights, with a trap success of $31 \%$. Cusack (2011) captured 523 individuals from 22 different species for 995 times in 3420 trap night, achieving a trap success of $29.1 \%$.

As a result, capturing rates of our study complies with the studies carried out in European forest habitats (Horváth and Kovačić, 2007). In this type of studies, trap success data in forest habitats show similarity when bait is not used. The capturing success varies in zoogeographic regions where species diversity, biomass, and abundance are high.

The most commonly captured species in this study were Apodemus spp. (54.9\%), followed by Mus macedonicus (15.2\%), Myodes glareolus (12.8\%), Microtus subterraneus (11.6\%), Crocidura suaveolens (4.3\%) and Dryomys nitedula (1.2\%), respectively. Kaynaş (2008), in her study comparing the successional phase of forests exposed to wildfires in different times, identified $75.7 \%$ of the individuals she captured as Apodemus mystacinus and 6.5\% as Apodemus flavicollis, revealing $82.2 \%$ of all captured individuals belonged to Apodemus spp. Also captured in the same study, that investigated the red pine forest floor and scrub areas, were Mus macedonicus (8.6\%), Crocidura suaveoles (7.7\%), Rattus rattus (0.7\%), and Dryomys nitedula (0.7\%). The only similarity between our study and that of Kaynaş (2008) is that both sampling studies were conducted on the undergrowth of coniferous forests, and that Apodemus spp. were the dominant species.

In the study by Şenol (2012) conducted on a deciduous forest floor, the dominant species were Apodemus spp. (80.1\%), followed by Myodes glareolus (12\%), Glis glis $(6.6 \%)$, and Muscardinus avellanarius $(0.5 \%)$. The ratios are similar in studies from Central and Southern Europe. Horváth and Kovačić (2007) captured 430 individuals in their study in Croatia, $77.2 \%$ of which were Apodemus spp. and 22\% were Myodes glareolus.

As a result, Apodemus spp. are the dominant small mammals in forest habitats, reaching a dominance value of $75 \%$ in mountain forests of medium altitudes. They were dominant in all kinds of forest floor in this study. They become a little rarer in 
agricultural areas, making up only 6-7\% of captured small mammals. Their optimum habitats in Central Europe are pure and mixed deciduous forests (Flowerdew et al., 1985). Based on the data from this study and other studies conducted in our country so far, they seem to be the dominant species in coniferous, mixed, and mixed deciduous forest habitats.

For some species, the number of captured individuals varied according to seasons. Although Apodemus spp. showed no big difference in any season, the highest number of captures were still made in September (93) and May (68). Şenol (2012) found the maximum population size for Apodemus spp. in June and March, the population density decreased after July, and increased again in November. It is known that population density generally increases in autumn (Horváth and Kovačić, 2007).

There was also no significant difference for Myodes glareolus and Crocidura suaveolens, but seasonal fluctuation is quite normal for Dryomys nitedula. Due to its hibernation behaviour and nutritional preferences, the species was found to be active in June, July, and August. The species showing the highest seasonal variation in relative population density in this study was Microtus subterraneus, whose population increased about 2-3 times in September, October, and November.

In the study area, we also recorded species of diurnal raptors and reptiles that can create hunting pressure on small mammals. We observed that the diurnal raptors used the area between May and September for feeding purposes, and the predator snakes (Dolichophis caspius, Elaphe quatuorlineata) were also active in the area between May and October.

An increase in the general population status in autumn may be due to the migration of diurnal raptors in September, and the hibernation of snake species in October, resulting in a decreased predator pressure particularly in open areas. The species that benefits the most from this decrease seems to be Microtus subterraneus. $M$. subterraneus individuals being the most common element in the diet of the tawny owl supports this view.

This study, covering all seasons except winter, showed the necessity for multiple study periods even for providing faunal data, and that the autumn period must be included in sampling as that is the season when small mammals reach peak densities.

Sex ratios of captured individuals showed no significant difference for Apodemus spp. $\left(\chi^{2}=0.28571 ; p=0.5929\right)$. In all habitats, 211 males and 205 females were captured, and the sex ratio was approximately 51:49. Sex ratios were also balanced for Mus macedonicus and Myodes glareolus considering all habitats and all study periods. However, a significant difference was in the mountain steppe habitat $(\chi 2=5.6$; $\mathrm{p}=0.01796$ ), which had a minimum distance of $50 \mathrm{~m}$ to the Populus tremula forest and was $140 \mathrm{~m}$ away from the conifer plantation. It is possible that male individuals, especially young males that survive the winter, increase their home range to find a partner.

To evaluate the captured small mammals at the community level, their indicator values were found for each habitat. The maximum $0.46 \mathrm{IndVal}$ for Apodemus spp. was not significant $(P=1.178)$. IndVal was also low for Mus macedonicus and Crocidura suaveolens, showing they are not indicator species for any particular habitat. Myodes glareolus was determined to be an indicator species for the Populus tremula forest as it generally preferred that habitat (IndVal $=42 \%)$ and was rarely seen in others. A study conducted in Croatia determined that M. glareolus was the indicator species by $29 \%$ among 4 species during summer months (Horváth et al., 2008). Horváth (2011) also 
determined M. glareolus as an indicator species by $51.31 \%$ after Micromys minutus, Apodemus sylvaticus, and Microtus arvalis among 16 species.

In this study, Microtus subterraneus was the dominant species of the steppe, and Dryomys nitedula preferred thermophilic deciduous forest habitats, which increased their values as indicator species.

We calculated the habitat similarities according to the Bray-Curtis similarity index. Habitats with the highest similarity in this study were the coniferous plantation and Abies forest (82.2\%). This is because the floor of both habitats have similar cover. They are usually occupied by opportunistic species (Mus macedonicus in this study) and have no diversity in terms of food (cone seeds, etc.). Therefore, these two habitats are not preferred by dominant species, and were found to be the two most similar habitats in terms of small mammal preference. Populus tremula forest and thermophilic deciduous forest were the other close habitats with a similarity of $79 \%$. This is possibly due to similar species composition and cover percentages in both habitats. Other habitats had low similarities, but the mountain steppe was the most different type of habitat, likely because Microtus subterraneus was the dominant species, and it had a rich food variety, and was possibly used as a wintering area in times without predator pressure.

We collected qualitative and quantitative data on small mammals by sampling forest areas showing vegetation difference, and investigated how these different habitats affect small mammal abundance. We compared the composition, structure and species richness of small mammal communities in different habitat types, and found considerable differences in the densities and species compositions of the small mammal fauna elements, even when the habitat sections were adjacent. The richest habitats were those with more subforest cover and with soils rich in organic matter. Coniferous forests and plantation sites were poor in small mammal fauna.

Acknowledgements. I wish to thank Dr. Burak Akbaba for their help in the field studies. Also, thanks to Deniz Candaş for the help in translation and final editing of this paper. Legal permissions for this study were provided by The Turkish Ministry of Agriculture and Forestry, General Directorate of Nature Conservation and National Parks. This study was supported by the Research Fund of Hacettepe University (Nr. FBA-2015-5840) and it is part of the PhD thesis of Şafak Bulut.

\section{REFERENCES}

[1] Aubry, K. B., Hayes, J. P., Biswell, B. L., Marcot, B. G. (2003): The ecological role of tree-dwelling mammals in western coniferous forests. - In: Zabel, C. J., Anthony, R. G. (eds.) Mammals Community Dynamics. Management and Conservation in the Coniferous Forests of Western North America. Cambridge University Press, Cambridge, UK, pp. 405-443.

[2] Barret, G. W., Peles, J. D. (1999): Small mammals ecology: A landscape perspective. In: Barret, G. W., Peles, J. D. (eds.) Landscape Ecology of Small Mammals. Springer, New York, pp. 1-8.

[3] Bowman, J., Sleep, D., Forbes, G., Edwards, M. (2000): The association of small mammals and coarse woody debris at log and stand scales. - Forest Ecology Management 124(2): 119-124.

[4] Buruldağ, E. (1999): Myomimus roachi (Bate 1937) (Mammalia; Rodentia)'nın Üreme Biyolojisi ve Davranışları Üzerine Araştırmalar. - Yüksek Lisans Tezi, Trakya Üniversitesi Fen Bilimleri Enstitüsü, Biyoloji Anabilim Dalı, 55 sayfa (In Turkish). 
[5] Carey, A. B., Horton, S. P., Biswell, B. L. (1992): Northern Spotted Owls: influence of prey base and landscape character. - Ecological Monographs 62: 223-250.

[6] Carey, A. B., Harrington, C. A. (2001): Small mammals in young forests: implications for management for sustainability. - Forest Ecocological Management 154: 289-309.

[7] Christy, J. E., Mack, R. N. (1984): Variation in demography of juvenile Tsuga heterophylla across the substratum mosaic. - Journal of Ecology 72: 75-91.

[8] Çolak, E., Yiğit, N., Verimli, R. (1994): Periodic cycles in food intake and body weight of juvenile Dormice, Glis glis orientalis Nehring, 1903 (Rodentia: Gliridae) in northern Anatolia. - Turkish Journal of Zoology 18: 241-244.

[9] Cusack, J. (2011): Characterising Small Mammal Responses to Tropical Forest Loss and Degradation in Northern Borneo Using Capture-Mark-Recapture Methods. - Master's thesis, Imperial College London.

[10] De Bellefeuille, S., Bélanger, L., Pettorelli, J. H., Cimon, A. (2001): Clear-cutting and regeneration practices in Quebec boreal balsam forest: effects on snowshoe hare. Canadian Journal of Forest Research 31(1): 41-51.

[11] Diker, E. (2007): Uludağ'ın böcekçil (Mammalia: Insectivora) ve kemirici (Mammalia: Rodentia) türleri. - Trakya Üniversitesi, Fen Bilimleri Enstitüsü (In Turkish).

[12] Dufrene, M., Legendre, P. (1997): Species assemblages and indicator species: the need for a flexible asymmetrical approach. - Ecological monographs 67(3): 345-366.

[13] Duguay, J. P., Wood, P. B., Miller, G. W. (2000): Effects of timber harvests on invertebrate biomass and avian nest success. - Wildlife Society Bulletin 28: 1123-1131.

[14] Flowerdew, J. R., Gurnell, J., Gipps, J. H. W. (1985): The ecology of woodland rodents: bank voles and wood mice. - The proceedings of a symposium held at the Zoological Society of London on 23rd and 24th of November 1984. No. 55. Clarendon Press.

[15] Flowerdew, J. R., Shore, R. F., Poulton, S. M. C., Sparks, T. H. (2004): Live trapping to monitor small mammals in Britain. - Mammal review 34(1-2): 31-50.

[16] Gür, H., Gür, M. K. (2005): Annual cycle of activity, reproduction, and body mass of Anatolian ground squirrels (Spermophilus xanthoprymnus) in Turkey. - Journal of Mammalogy (ISI, SCI) 86: 7-14.

[17] Gür, H., Barlas, N. (2006): Sex ratio of a population of Anatolian ground squirrels Spermophilus xanthoprymnus in Central Anatolia, Turkey. - Acta Theriologica (ISI, SCI) 51: 61-67. doi: 10.1007/BF03192656.

[18] Hammer, O., Harper, D. A. T., Ryan, P. D. (2001): PAST: Paleontological Statistic software package for education and data analysis. - Paleontologia Eletronica 4(1): 1-9.

[19] Hansson, L. (1998): Local hot spots \& their edge effects: small mammals in oak-hazel woodland. - Oikos 81: 55-62.

[20] Horváth, Gy., Kovačić, D. (2007): Protokol za praćenje populacija i zajednica sitnihsisavaca na staništima duž Drave. [Protocol for the monitoring of small mammal populations and communities in habitats along the river Drava]. - In: Purger, J. J. (ed.) Priručnik za istraživanje bioraznolikosti duž rijeke Drave. [Manual for the investigation of biodiversity along the river Drava]. University of Pécs, pp. 219-234.

[21] Horváth, Gy., Borsics, J., Purger, J. J. (2008): Habitat use of small mammals in disturbed patches of Haljevo forest in Croatia. - University of Pécs Publish.

[22] Horváth, Gy., Herczeg, R., Tamási, K., Sali, N. (2011): Nestedness of small mammal assemblages and role of indicator species in isolated marshland habitats. - Natura Somogyiensis 19: 281-283.

[23] Irmak, S. (2012): Zonguldak ili Erinaceomorpha, Soricomorpha ve Chiroptera (Chordata: Mammalia) türlerinin ve yayılışlarının belirlenmesi. - Bülent Ecevit Üniversitesi, Fen Bilimleri Enstitüsü (in Turkish).

[24] Karataş, A. (1996): Yamanlar dağı (İzmir) Mammalia (Insectivora, Chiroptera, Rodentia) faunası. - Ege Üniversitesi, Fen Bilimleri Enstitüsü (in Turkish). 
[25] Kaynaş, B. Y. (2008): Pinus brutia orman ekosistemlerinde küçük memeli komünitesi üzerine yangının uzun dönem etkisi ve yangın sonrası komünite yapısının değişimi üzerine çalışmalar. - Hacettepe Üniversitesi, Fen Bilimleri Enstitüsü (in Turkish).

[26] Kirkland Jr, G. L., Johnston Jr, T. R., Steblein, P. (1985): Small mammal exploitation of a forest-clearcut interface. - Acta Theriologica 30: 211-218.

[27] Korpimaki, E., Lagerstrom, M., Saurola, P. (1987): Field evidence for nomadism in Tengmalm's Owl Aegolius funereus. - Ornis Scandinavica 18: 1-4.

[28] Lautenschlager, R. A. (1993): Response of wildlife to forest herbicide applications in northern coniferous ecosystems. - Canadian Journal of Forest Research 23: 2286-2299.

[29] Luoma, D. L., Trappe, J. M., Claridge, A. W., Jacobs, K., Cazares, E. (2003): Relationships among fungi and small mammals in forested ecosystems. - In: Zabel, C. J., Anthony, R. G. (eds.) Mammal Community Dynamics. Management and Conservation in the Coniferous Forests of Western North America. Cambridge University Press, Cambridge, UK, pp. 343-373.

[30] Manson, H. R., Ostfeld, R. S., Canham, C. D. (1999): Responses of a small mammal community to heterogeneity along forest-old-field edges. - Landscape Ecology 14: 355367.

[31] McShea, W. J., Rappole, J. H. (2000): Managing the abundance and diversity of breeding bird populations through manipulation of deer populations. - Conservation Biology 14(4): 1161-1170.

[32] Medin, D. E., Booth, G. D. (1989): Responses of Birds and Small Mammals to SingleTree Selection Logging in Idaho. - US Department of Agriculture, Forest Service Intermountain Research Station, Ogden, Utah, Research Paper INT: 408.

[33] Nakagawa, M., Miguchi, H., Nakashizuka, T. (2006): The effects of various forest uses on small mammal communities in Sarawak, Malaysia. - Forest Ecology and Management 231(1): 55-62.

[34] Nickel, A. M., Danielson, B. J., Moloney, K. A. (2003): Wooded habitat edges as refugia from microtine herbivory in tallgrass prairies. - Oikos 100: 525-533.

[35] Odum, E. P., Barrett, G. W. (2005): Fundamentals of ecology. - 5th edition Belmont, CA: Thomson Brooks/Cole.

[36] Özkan, B., Yiğit, N., Çolak, E. (2003): Türkiye Trakyası'nda Micromys minutus Pallas, 1777 (Mammalia: Rodentia) üzerine bir çalışma. - Turkish Journal of Zoology 27: 55-60. (in Turkish).

[37] Özkurt, Ş., Yiğit, N., Çolak, E., Sözen, M., Verimli, R. (2001): Observations on the reproduction biology of Meriones meridianus Pallas, 1773 (Mammalia: Rodentia) in Turkey. - Zoology in the Middle East 23: 23-29.

[38] Özkurt, Ş., Yiğit, N., Çolak, E., Sözen, M., Gharkheloo, M. M. (2005): Observations on the Ecology, Reproduction and Behavior of Spermophilus Bemnett, 1835 (Mammalia: Rodentia) in Turkey. - Turkish Journal of Zoology 29: 91-99.

[39] Payer, D. C., Harrison, D. J. (2000): Structural differences between forests regenerating following spruce budworm defoliation and clear-cut harvesting: implications for marten. - Canadian Journal of Forest Research 30: 1965-1972.

[40] Pearce, L., Venier, L. (2005): Small mammals as bioindicators of sustainable boreal forest management. - Forest Ecology and Management 208: 153-175.

[41] Şenol, D. (2012): Zonguldak bölgesi karışık yaprak döken orman alanında yaşayan kemiricilerin (Mammalia: Rodentia) populasyon büyüklüklerinin markalama yöntemiyle belirlenmesi. - Bülent Ecevit Üniversitesi, Fen Bilimleri Enstitüsü.

[42] Steventon, J. D., Mackenzie, K. L., Mahon, T. E. (1998): Responses of small mammals and birds to partial cutting and clearcutting in northwest British Columbia. - The Forestry Chronicle 74: 703-713.

[43] Sullivan, J. L., Piereson, J. E., Marcus, G. E., Fledman, S. (1979): The More Things Change, The More They Stay the Same: The Stability of Mass Belief Systems. American Journal of Political Science 23: 176-86. 
[44] Sullivan, W., Fogarty, P., Theurkauf, W. (1993): Mutations affecting the cytoskeletal organization of syncytial Drosophila embryos. - Development 118: 1245-1254.

[45] Tüzün, T. E. (2012): Beytepe (Ankara) karasal küçük memeli faunasının belirlenmesi. Hacettepe Üniversitesi, Fen Bilimleri Enstitüsü (in Turkish).

[46] Verts, B. J., Carraway, L. N. (1998): Land Mammals of Oregon. - University of California Press, Berkeley. xvi + 668 pp. ISBN 0- 520-21199-5.

[47] Wells, K., Kalko, E. K. V., Lakim, M. B., Pfeiffer, M. (2007): Effects of rain forest logging on species richness and assemblage composition of small mammals in Southeast Asia. - Journal of Biogeography 34(6): 1087-1099.

[48] Yavuz, G. (2007): Ankara civarında yayı1lış gösteren su sıçanı Arvicola terrestris L., 1758 (Mammalia: Rodentia)'in ekolojisi üzerinde araştırmalar. - Ankara Üniversitesi, Fen Bilimleri Enstitüsü (in Turkish).

[49] Yiğit, N., Çolak, E., Özkurt, Ş. (1995): Biology of Meriones tristrami Thomas, 1892 (Rodentia: Gerbillinae) in Turkey. - Turkish Journal of Zoology 19: 337-341.

[50] Yiğit, N., Kıvanç, E., Çolak, E. (1997): Diagnostic characters and distribution of Meriones Illiger, 1811 (Mammalia: Rodentia) in Turkey. - Turkish Journal of Zoology 21: 361-374. (article in Turkish with an abstract in English).

[51] Zar, J. H. (1996): Biostatistical analysis. - Prentice-Hall, New Jersey. 